\title{
Results of the post flash-flood disaster investigations in the Transylvanian Depression (Romania) during the last decade (2001-2010)
}

\author{
V. Arghiuş, A. Ozunu, I. Samara, and G. Roşian \\ Babeş-Bolyai University, Faculty of Environmental Science and Engineering, Cluj-Napoca, Romania \\ Correspondence to: V. Arghiuş (arghius.viorel@ubbcluj.ro)
}

Received: 6 June 2013 - Published in Nat. Hazards Earth Syst. Sci. Discuss.: 5 November 2013

Revised: 6 August 2013 - Accepted: 3 February 2014 - Published: 4 March 2014

\begin{abstract}
Flash-flood disasters are very rare in the Transylvanian Depression. In the last decades just three events were signalled in the study area, all of them during the last 10 years. The flash floods occurring in the study area during the last decade had a significant impact on several localities situated at the Transylvanian Depression border. Based on the post flash-flood investigation, the present study intends to find out the main characteristics of the flash floods and the causes that have led to disasters in a region rarely affected by such kinds of events. Analyzing the hydrological data, it has been seen that the maximum intensity of the flash floods was observed in the upper and middle basins. By comparing the unit peak discharges from the studied region with other specific peak discharges related to the significant flash floods from Romania, it was noticed that the events from the Transylvanian Depression have moderate to low intensity. On the other hand, the results showed that besides high stream power and unexpected character common to flash floods, the inappropriate flood risk management measures increased the dimension of the negative effects, leading to tens of lives lost and economical damages of tens of millions of dollars.
\end{abstract}

\section{Introduction}

Flash floods are one of the most significant natural hazards in Europe, causing serious risk to life and the destruction of buildings and infrastructure (Gaume et al., 2009; Aronica et al., 2012). The potential for flash-flood casualties and damages is also increasing in many regions due to social and eco- nomic development bringing pressure on land use (Marchi et al., 2010).

However, the flash-flood events are poorly understood due to the lack of experimental sites and long-term hydrometeorological data with adequate space-time resolution (Foody et al., 2004; Delrieu et al., 2005; Manus et al., 2009). Such phenomena are difficult to predict accurately, raising warning problems. Thus, flash-flood forecasting, warning and emergency management are, by their nature, suitable for coping with the characteristics of flash-flood risk (Drobot and Parker, 2007; Marchi et al., 2010).

The effective documentation of flash floods requires postflood survey strategies encompassing accurate radar rainfall estimation, field observations of the hydro-geomorphic processes associated with the flood, indirect reconstruction of peak discharges and interviews of eye witnesses (Arghiuş, 2008; Marchi et al, 2009). Post-flood surveys appear clearly as a necessity to increase the existing knowledge of such events in order to provide proper methods of analysis and technical solutions for flood prevention and control (Borga et al., 2007; Gaume and Borga, 2008; Rusjan et al., 2009; Roca and Davison, 2010). Flash flood-related studies are particularly useful, helping to complete the flash-flood event databases (peak discharges, unit peak discharges, damages), which are limited both in Romania and in Europe. A good knowledge of this type of event and any improvement in its numerical modeling can also be an invaluable aid for forecasting and alert systems (Pastor et al., 2010). On the other hand, if the number of such studies increases, better regional envelope curves for flash floods can be developed 


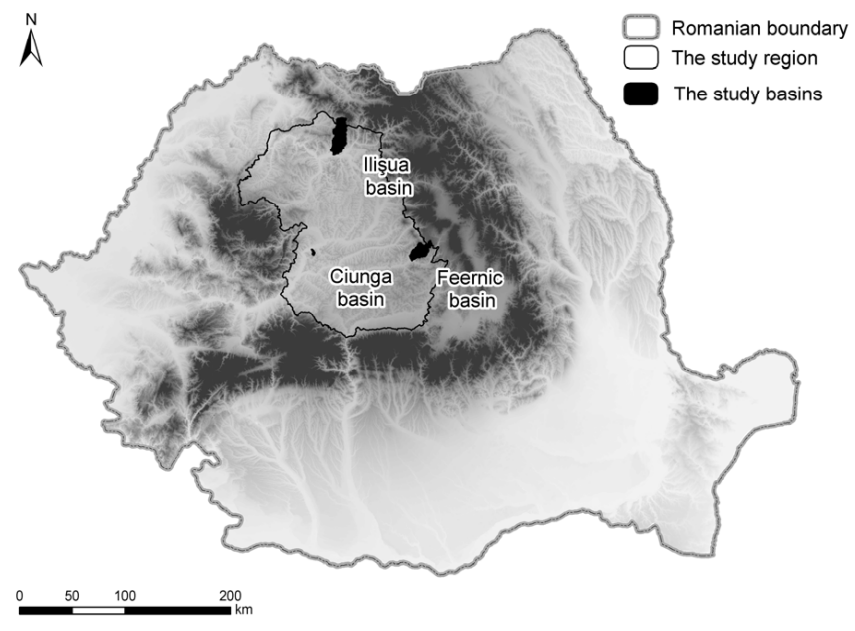

Fig. 1. The location of the study areas.

more easily and the hazard in risk equations can be more accurately assessed.

\section{The general context of the study area}

The region subjected to study $\left(24552 \mathrm{~km}^{2}\right)$, the Transylvanian Depression, is located in the central-northern part of Romania, including watercourses that belong to three major basins: the Someş, Mureş and Olt (Fig. 1).

The region is bordered by the Carpathians on almost every side, being one of the largest depressions in Europe. The depression is divided into two major units. One of them occupies a very large area in the central part of the region (the Transylvanian Plateau) and the other, including the so-called "Peri-Transylvanian depressions and hills", is located at the border.

The altitudes range between $180 \mathrm{~m}$ a.s.l. in the northwestern part and $1080 \mathrm{~m}$ a.s.l on the eastern side (Bicheş Peak). The depression overlaps a relatively small variety of rocks, especially sedimentary rocks like marl, clay, salt and alluvial deposits.

The climate is continental temperate, showing a strong influence of the westerlies. The mean annual temperature in the region is $\sim 6-9{ }^{\circ} \mathrm{C}$, while mean annual precipitation ranges between $1000 \mathrm{~mm}$ on the extreme eastern side exposed to the westerlies, and less than $500 \mathrm{~mm}$ in the western part that is affected by pseudo-adiabatic processes and foehn-type winds.

The localities network within the studied area includes a number of 391 administrative-territorial units (347 communes and 44 towns). The population belonging to the Transylvanian Depression is about 2.6 million inhabitants, thus a demographic density of 106 inhabitants $\mathrm{km}^{-2}$ results. The highest population density is specific to the lower altitude in the major valley corridors and in the border depressions, many inhabitants being located in the flood-prone area.
Being mostly a hilly region with relatively low drainage density and large basins with mild slopes, floods belong especially to the slow-onset flood type. Nevertheless, at the border with the Carpathians, the basin's slope gradient becomes steeper, increasing the flash-flood hazard.

\section{Methods and data}

To include the analysed flash-flood events in the natural disasters category, the definitions in the EM-DAT glossary (http://www.emdat.be/glossary/9) were considered, where a disaster is:

- a situation or event that overwhelms local capacity, necessitating a request to national or international level for external assistance;

- an unforeseen and often sudden event that causes great damage, destruction and human suffering.

For flash-flood disaster investigations, several main sets of data, including the meteorological context, the peak discharge parameters, the evolution in time and space of flash floods and the social and economic negative effects have been analyzed.

In order to study the meteorological context, both the data on the rainfall events (rain gauge measurement data and especially the radar image data, provided by the Romanian National Meteorological Administration, RNMA), and the synoptic maps were collected and analyzed. The quantitative precipitation estimation problem is particularly crucial and difficult in the context of flash floods since the causative rain events may develop at very short space and timescales (Tarolli et al., 2012). Hourly radar-raingauge combined estimates are routinely used as an alternative precipitation input for hydrological models (Salek et al., 2006). The WSR98D Doppler radar located at Bobohalma that covers the entire study region, generating NEXRAD products like onehour precipitation, three-hour precipitation and total storm precipitation. The temporal resolution of the data is $6 \mathrm{~min}$, while the spatial resolution is $1^{\circ} \times 2 \mathrm{~km}$ (polar) (http://www. meteoromania.ro/index.php?id=432).

Based on the streamgauge station data, the hydrologic response was examined. Unfortunately, the upstream basins where the most severe flash floods took place are ungauged. There are a number of methods that can be applied to study extreme floods on ungauged watersheds, including the so-called "indirect" peak discharge estimates and rainfallrunoff modeling through hydrological models (Gaume et al., 2009; Koutroulis and Tsanis, 2010). Empirical relations must be used with caution and estimates should be made at a minimum of two or three cross sections for the same river reach to reduce uncertainties (Gaume et al., 2004; Gaume, 2006; Koutroulis and Tsanis, 2010). 
Considering the above recommendations, besides the recorded data, results of hydraulic modeling from other related studies were used to supplement the database.

When the data were poor or missing (e.g., the Feernic and Ciunga basins), the post-event surveys was performed. In this situation, the peak discharges were estimated based on the cross-section surveys using the classic hydraulic formula

$Q=A \cdot V$,

where

$Q$ - peak discharge $\left(\mathrm{m}^{3} \mathrm{~s}^{-1}\right)$;

$A$ - cross-sectional wetted areas $\left(\mathrm{m}^{2}\right)$;

$V$ - mean flow velocity $\left(\mathrm{ms}^{-1}\right)$.

The mean flow velocity $(V)$ is computed using the Manning-Strickler empirical formula

$V=n^{-1} R^{0,67} S^{0,50}$.

where

$n$ - roughness coefficient;

$R$ - hydraulic radius (m);

$S$ - water surface slope $\left(\mathrm{mm}^{-1}\right)$.

For a proper adjustment and in order to reduce the uncertainty related to the estimation of peak discharges, additional measures were adopted:

- the appropriate cross sections were chosen;

- the section has been subdivided into a main channel area and a right and left overbank flow area, and the discharge was calculated separately for each of the sub-areas (Gaume, 2006; Gaume and Borga, 2008);

- interviews addressed to eye witnesses about the timing of rainfalls and flash floods;

- the comparison with other available investigation data related to studied events.

The analysis of the social effects and direct, tangible damages was based on quantitative data, including the event flood reports of the County Committees for Emergency Situations and County Prefect's Houses. Such investigations require normalization of event loss values (goods and assets values and the cost of repairs/replacements) for changes in inflation (Barredo, 2009; Arghiuş et al., 2011). Thus, using the annual average values of the implicit price deflator, an adjustment of damage costs at the values of goods and services in the year 2005 was performed.

\section{Results and discussions}

Flash-flood disasters are very rare in the Transylvanian Depression. Therefore, none of the significant flash floods that hit Romania during the second half of the 20th century are to be found in the study region. During the last decade (i.e., the 2001-2010 period), the occurrence of such events has increased throughout the country, as flash floods are listed first in the natural disaster category, in terms of lives lost. The study area was also impacted by these events. The three most significant flash floods occurring in the study area during the last decade (the Feernic, August 2005, Ilişua, June 2006 and Ciunga, June 2010 events) had a significant impact on many localities from the study area.

\subsection{Meteorological context}

The meteorological analysis of the flash-flood events was focused on the synoptic conditions for heavy, localized rainfall over the study basins and quantitative precipitation estimation.

The long-time observations showed that the most significant flash floods in Romania are specific to the warm season when, beside frontal precipitation, intense convective processes are developed. In this season, the heavy rainfall events typically occur downstream of a significant cyclone aloft, often exhibiting "cut-off" cyclone nucleuses (Arghiuş, 2008, Stăncălie et al., 2010) (Fig. 2). The same situation was observed in the studied areas. In this context the height cold nucleuses maintain the cyclonic activity at ground level and increase the atmospheric instability in the lower and middle troposphere, leading to the rapid and massive condensation processes and to short-lived heavy rainfalls (Arghiuş and Maloş, 2009). The situation at sea level shows a distribution of the baric systems that includes a field of high atmospheric pressure (the Azores High) developed from southwestern to central Europe, and a Mediterranean cyclone in the southwestern part of Romania. Under these conditions, the ground-level air circulation is predominantly southern.

The above-mentioned circumstances led to heavy rainfalls in the study basins. As in other situations, extreme rainfall events that triggered the analyzed flash floods are not only characterized by quite huge precipitation rates, but also by a quasi-stationary behavior (Anquetin, 2009). In the studied watersheds the heavy rainfalls had ranging durations, from $1.5-2 \mathrm{~h}$ in the Ciunga Basin to $8-9 \mathrm{~h}$ in the Ilişua Basin (Table 1).

The precipitation reconstruction based on radar images showed maximum rainfall rates varying from $102 \mathrm{~mm} \mathrm{~h}^{-1}$ (Feernic Basin) to $76 \mathrm{~mm} \mathrm{~h}^{-1}$ (Ciunga Basin) (Fig. 3), while the total storm event recorded values that reached up to $175 \mathrm{~mm}$ on the eastern side of the Feernic Basin, $160 \mathrm{~mm}$ in the northeast of the Ilişua Basin and $90 \mathrm{~mm}$ in the southern part of the Ciunga Basin.

The highest amount of precipitation fell in the upper and middle basin areas, overlapping the steeper terrains. The maximum rain rate was recorded at the end of the afternoon and the beginning of the evening, when the convective potential usually shows the highest values.

In all case studies light precipitation and heavy rainfall had saturated soils prior to flash-flood events. Thus, three weeks 


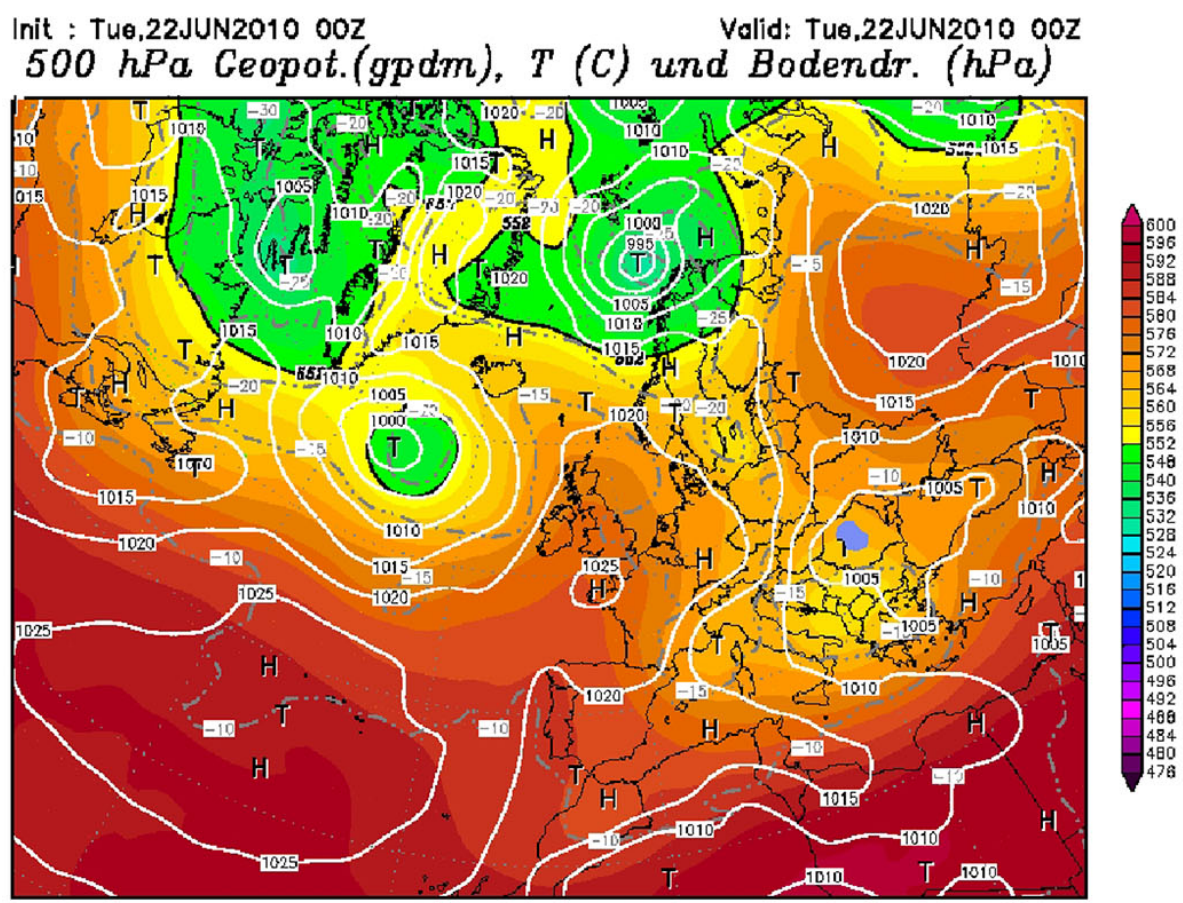

Doten: GFS-Modell de
(C) Wetterzentrale
www.wetterzentrole.de

Init : Tue,23AUg2005 00Z Valid: Tue,23AUg2005 00Z

$500 \mathrm{hPa}$ Ceopot. (gpdm), T (C) und Bodendr. (hPa)
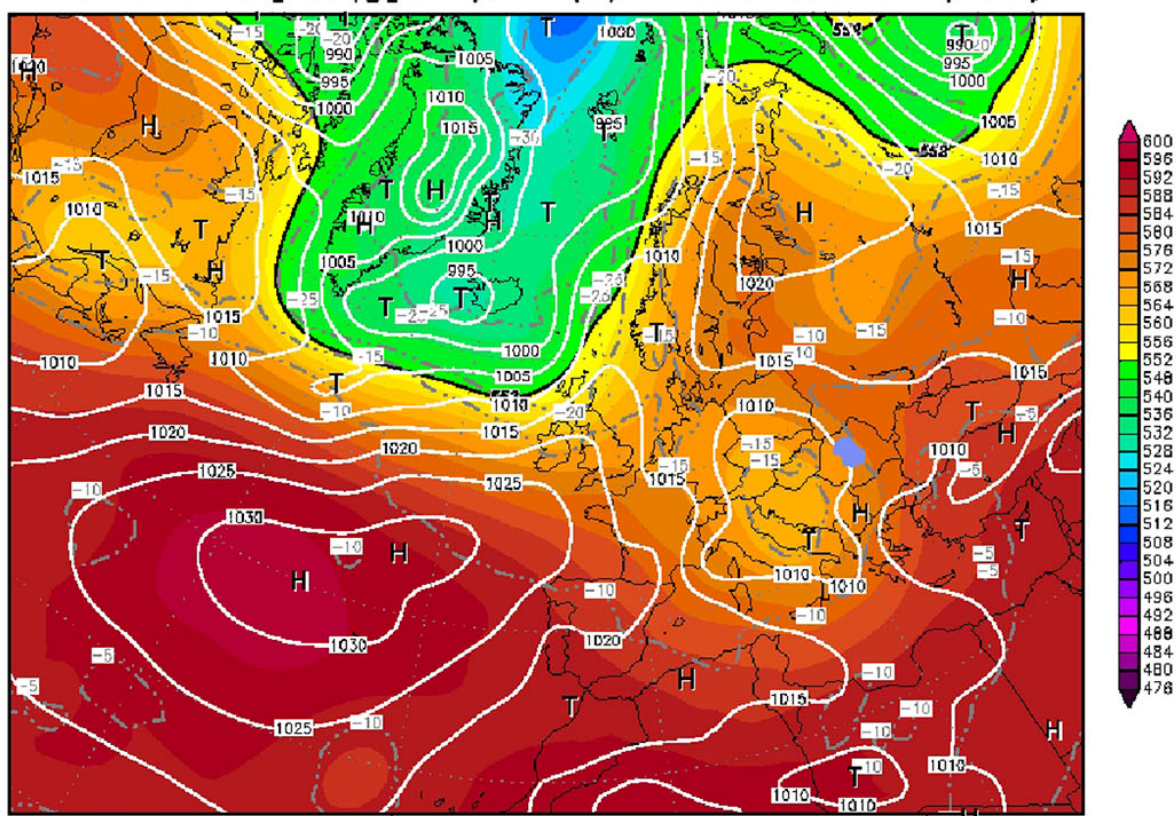

b) (C) Wetterzentrale

Transylvanian Depression

Fig. 2. Sea level pressure (hPa), $500 \mathrm{hPa}$ geopotential height (gpdm) and temperature $\left({ }^{\circ} \mathrm{C}\right)$ in the Feernic 2005 (a) and Ciunga 2010 (b) flash-flood events (http://www.wetterzentrale.de/topkarten/fsavneur.html). 

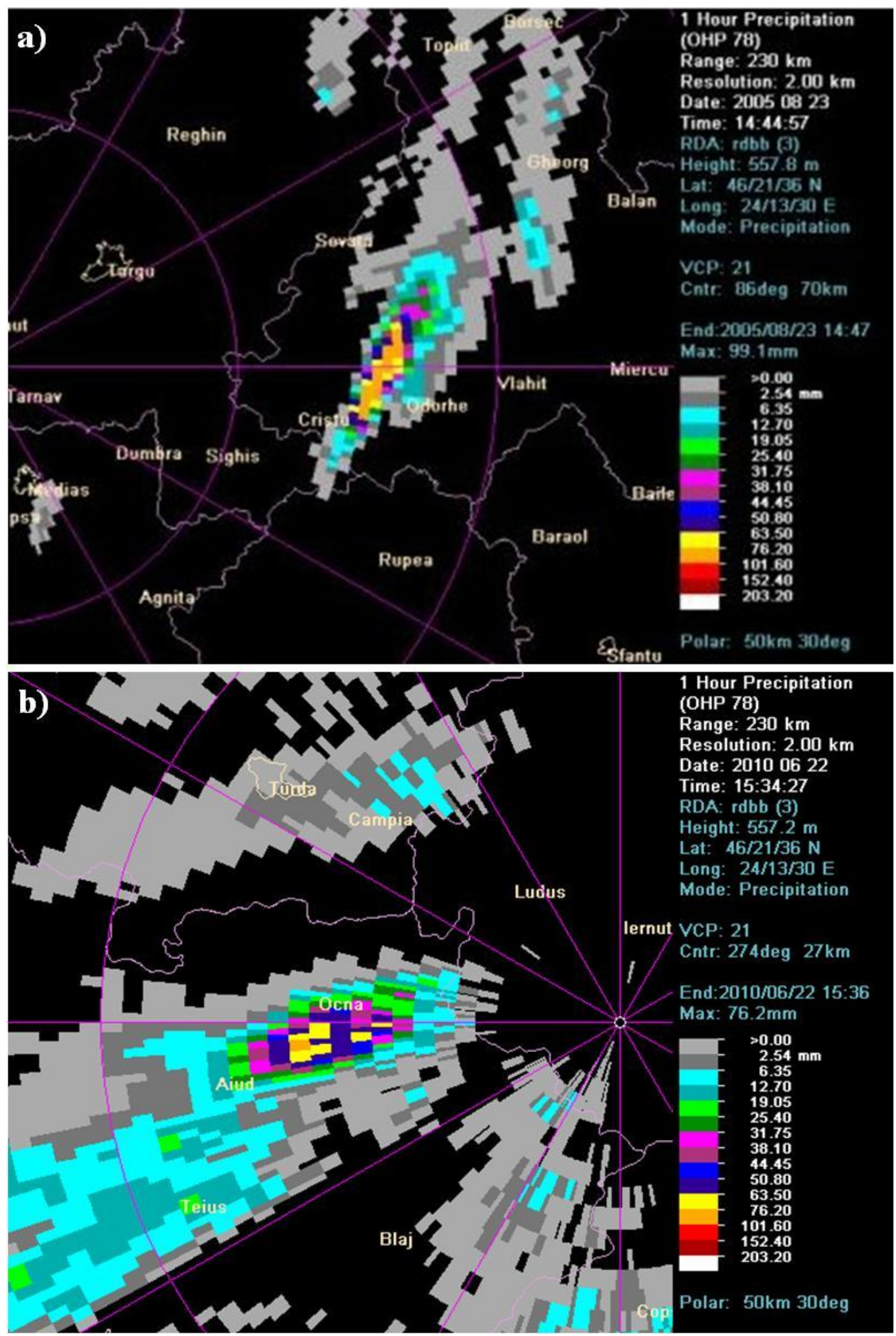

Fig. 3. The estimation of rainfall rates $\left(\mathrm{mm} \mathrm{h}^{-1}\right)$ with the Doppler radar in the (a) Feernic and (b) Ciunga basinal areas (source of radar images: "Transilvania Nord" regional meteorological center ). 
Table 1. Rainfall characteristics for the surveyed basins.

\begin{tabular}{lccccc}
\hline Basins & $\begin{array}{l}\text { Total rain at the } \\
\text { neareast raingauge } \\
\text { stations (mm) }\end{array}$ & Storm duration $(\mathrm{h})$ & $\begin{array}{l}\text { Total basin } \\
\text { rain/event }(\mathrm{mm})\end{array}$ & $\begin{array}{l}\text { Highest rain rate } \\
\text { shown on radar } \\
\text { images }\left(\mathrm{mm} \mathrm{h}^{-1}\right)\end{array}$ & $\begin{array}{l}\text { Periods with } \\
\text { highest rain rates } \\
(\text { hour intervals) }\end{array}$ \\
\hline Feernic & 56 & $5-6$ & $0-175$ & 102 & $17.00-17.40$ \\
Ilişua & 60 & $8-9$ & $15-16$ & - & $16.15-17.15$ \\
Ciunga & 70 & $1.5-2$ & $70-9$ & 76 & $18.15-18.40$ \\
\hline
\end{tabular}

Table 2. The main characteristics of the study basins.

\begin{tabular}{lllllllll}
\hline River & $\begin{array}{l}\text { Number of } \\
\text { stream } \\
\text { gauge } \\
\text { stations }\end{array}$ & $\begin{array}{l}\text { Length } \\
(\mathrm{km})\end{array}$ & $\begin{array}{l}\text { Channel } \\
\text { slope } \\
\left(\mathrm{m} \mathrm{km}^{-1}\right)\end{array}$ & $\begin{array}{l}\text { Average } \\
\text { basin slope } \\
(\%)\end{array}$ & $\begin{array}{l}\text { Drainage } \\
\text { area } \\
\left(\mathrm{km}^{2}\right)\end{array}$ & $\begin{array}{l}\text { Mean basin } \\
\text { elevation } \\
(\mathrm{m} \text { a.s.1.) }\end{array}$ & $\begin{array}{l}\text { Afforestation } \\
\text { coefficient } \\
(\%)\end{array}$ & $\begin{array}{l}\text { Population } \\
\text { density } \\
\left.(\mathrm{inh} \mathrm{km})^{-2}\right)\end{array}$ \\
\hline Ilişua & 1 & 52.0 & 15.0 & 21.1 & 356 & 516 & 31.7 & 36.5 \\
Feernic & 1 & 33.0 & 16.0 & 12.9 & 194 & 634 & 20.3 & 43.8 \\
Ciunga & Ungaged & 6.31 & 27.1 & 13.0 & 9.24 & 365 & 19.0 & 134 \\
\hline
\end{tabular}

before the events the amounts of precipitation were between $28-53 \mathrm{~mm}$ in the Ilisua watershed and $100-200 \mathrm{~mm}$ in the Feernic Basin.

\subsection{Analysis of flash floods}

Extreme rainfall falling on saturated soil, especially in the upper part of the basins, resulted in severe flooding in the Feernic, Ilişua and Ciunga watersheds (Fig. 4). The main characteristics related to the selected basins are listed in Table 2. Streamgauge station data provided by the Romanian Waters National Administration (RWNA) and investigations from post-event surveys (Fetea et al., 2006; Hydrate Project and our field investigations), combined with hydraulic modeling from another related study (Sangati, 2009), were used to examine hydrologic response to the storm.

Unfortunately, just two streamgauge stations are located in the study basins (Feernic River - Şimoneşti streamgauge station; Ilişua River - Cristeştii Ciceului streamgauge station), both being located near the mouth of the rivers. The flash floods recorded at these two streamgauge stations are shown in Fig. 5.

Analysing the hydrographs, a sudden peak rising can be observed that indicates features related to flash floods. Along with the heavy rain rates in the upper basins, the sudden rise in the peak discharges was influenced by the failure of a series of temporary wooden debris dams that were formed in narrow valley sections. Four important dams were reported in the Ilişua watershed and one in the Feernic River basin. Another study (Sangati, 2009) in the Feernic Basin confirms the above mentions. Thus, the recorded discharge values at the Şimoneşti streamgauge station show a sudden peak rising, while the simulated hydrograph in the same section follows a milder curve. As the author has observed, the impulsivity of the registered hydrograph could depend on the blockagerelease effect due to wood and solid material passing through narrow cross sections, while this dynamic is not considered by the model (Sangati, 2009).

Based on flood marks, it has been found that the maximum water level (reported to the thalweg level) ranged from $5.0 \mathrm{~m}$ (Lupeni village - Feernic event) to $4.8 \mathrm{~m}$ (Târlişua village Ilişua event) and $4.0 \mathrm{~m}$ (Uioara de Jos village - Ciunga event) (Fig. 6).

To enable the comparison of flood intensities on the different watersheds, the unit peak discharges are calculated (Table 3). Analysing the data, it can be seen that the maximum intensity of the flash floods was observed in the upper and middle basins where the unit peak discharges showed the highest values. These observations are in accordance with the radar rainfall data.

Along the Ilişua River, which presents a broad floodplain downstream to the village of Târlişua, a peak attenuation was observed.

By comparing the unit peak discharges from the studied region with other specific peak discharges related to the significant flash floods from Romania, it was noticed that the flash-flood events from the Transylvanian Depression have moderate to low intensity (Fig. 7). Nevertheless, in some areas from this region even low-intensity flash floods can trigger disasters considering that the floodplains are generally associated with high demographic density.

\subsection{Impact events}

Despite the warnings, the preparedness and operational measures were minimal, such that consequences were very severe, with substantial disruption to the local economy and many lives lost. 
Table 3. The flash-flood peak disharges and unit peak discharges in the analyzed cross sections.

\begin{tabular}{|c|c|c|c|c|c|}
\hline River & $\begin{array}{l}\text { Cross-section } \\
\text { location }\end{array}$ & $\begin{array}{l}\text { Drainage } \\
\text { area } \\
\left(\mathrm{km}^{2}\right)\end{array}$ & $\begin{array}{l}\text { Mean basin } \\
\text { elevation } \\
\text { (m a.s.1.) }\end{array}$ & $\begin{array}{l}\text { Peak } \\
\text { discharge } \\
\left(\mathrm{m}^{3} \mathrm{~s}^{-1}\right)\end{array}$ & $\begin{array}{l}\text { Unit peak } \\
\text { discharge } \\
\left(\mathrm{m}^{3} \mathrm{~s}^{-1} \mathrm{~km}^{-2}\right)\end{array}$ \\
\hline Ilisua & $\begin{array}{l}\text { Upstream } \\
\text { Târlişua }^{a}\end{array}$ & 57 & - & 193 & 3.39 \\
\hline Ilisua & $\begin{array}{l}\text { Downstream } \\
\text { Târlişua }^{b}\end{array}$ & 160 & 562 & 280 & 1.75 \\
\hline Ilisua & $\begin{array}{l}\text { Cristeştii Ci- } \\
\text { ceului station }\end{array}$ & 353 & 562 & 212 & 0.60 \\
\hline Feernic & Lupeni & 32.2 & 841 & 132 & 4.10 \\
\hline Feernic & $\begin{array}{l}\text { Simoneşti } \\
\text { station }^{\mathrm{c}}\end{array}$ & 145 & - & 368 & 2.54 \\
\hline Ciunga & $\begin{array}{l}\text { Upstream } \\
\text { Uioara de Jos }\end{array}$ & 6.02 & 420 & 58 & 9.63 \\
\hline
\end{tabular}

a DHydrate project (http://www.hydrate.tesaf.unipd.it/WareHouse/EuropeanDataCenter/Romania/); ${ }^{\text {b }}$ Fetea et al. (2006); ${ }^{\mathrm{c}}$ RWNA.

Table 4. The impact of analyzed flash-flood events on socio-economic life.

\begin{tabular}{llllll}
\hline $\begin{array}{l}\text { Flash-flood } \\
\text { events }\end{array}$ & $\begin{array}{l}\text { Number of } \\
\text { deaths }\end{array}$ & $\begin{array}{l}\text { Damages } \\
\text { (millions cur- } \\
\text { rent USD) }\end{array}$ & $\begin{array}{l}\text { GDP } \\
\text { Deflator }^{\mathrm{a}}\end{array}$ & $\begin{array}{l}\text { Damages } \\
\text { (millions } \\
\text { 2005 USD) }\end{array}$ & $\begin{array}{l}\text { Per capita } \\
\text { damages } \\
\text { (2005 USD) }\end{array}$ \\
\hline $\begin{array}{l}\text { 2005, } \\
\text { Feernic }\end{array}$ & 16 & 34.82 & 1 & 34.82 & $769^{\mathrm{b}}$ \\
$\begin{array}{l}\text { Basin } \\
\text { 2006, }\end{array}$ & 13 & 37.98 & 1.106 & 34.34 & 2641 \\
$\begin{array}{l}\text { Ilişua Basin } \\
\text { 2010, }\end{array}$ & 1 & 0.629 & 1.52 & 0.414 & 335 \\
$\begin{array}{l}\text { Ciunga } \\
\text { Basin } \\
\text { Total }\end{array}$ & 30 & 73.4 & & & \\
\hline
\end{tabular}

${ }^{a}$ UNCE, Statistical Database 2000-2010; ${ }^{\mathrm{b}}$ including the Odorheiu Secuiesc population.

Among the social effects, the most sensitive issue is associated with the loss of human lives. The studied flash floods were responsible for 30 lives lost. This value represents $15 \%$ of the total number of casualties caused by floods and flashflood events in Romania during the 2001-2010 period. Most of them $(66 \%)$ were helpless elderly people, more vulnerable to such events.

The analysis of the economic damages was performed based on reports of the County Committees for Emergency Situations and County Prefect's Houses. For the 2005 Feernic event the damage report was available for the entire affected area, including Odorheiu Secuiesc, a town located outside the Feernic watershed. Counting the direct, tangible damages caused by the analyzed flash-flood events, the total summed up to 2005 USD 69574000 (Table 4). During the 2001-2010 period, this value represented $1.50 \%$ of the cumulated value of the entire country (2005 USD 69574000 as compared to 2005 USD 4.678 billion), whereas the population of the studied areas represents only $0.11 \%$ of the country's total population.

\section{Conclusions and lessons learned}

The research showed that the most vulnerable areas to flash floods in the study region are the basins from the eastern and northern parts, which have steeper slopes and small size.

By comparing the unit peak discharges with other specific flash-flood peak discharges from Romania, it was noticed that the flash-flood events from the study region are rare events and have moderate intensity. Nevertheless, in some areas from this region even moderate- and low-intensity flash floods can trigger disasters.

The high level of damage and many lives lost that accompanied the flash floods were influenced by a lot of factors.

The main factor is associated with natural causes. Thus, heavy rainfalls falling on saturated soil, mainly in the upstream steeper basins, led to a rapid concentration of water in the river beds and a sudden rise in the water levels and discharges. 


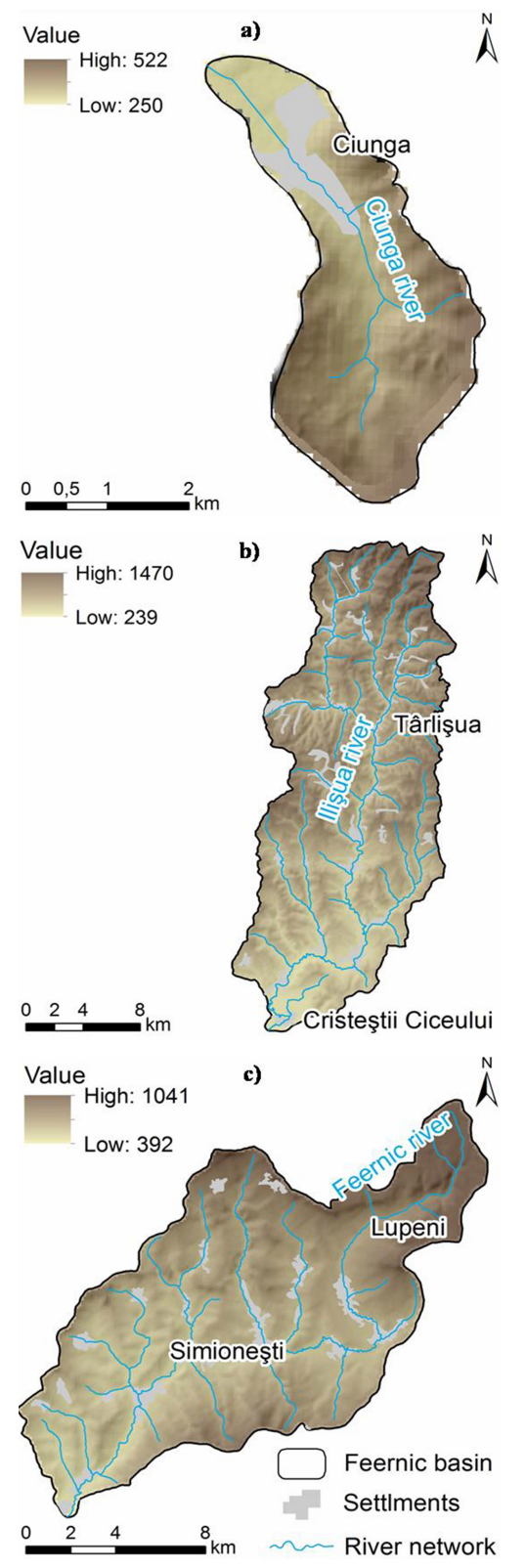

Fig. 4. The studied watershades: (a) Feernic Basin, (b) Ilişua Basin and (c) Ciunga Basin.

On the other hand, although the demographic density in the Ilişua and Feernic basins represents less than a half the national average population density (see Table 2), the frequent mass-movement processes from the hillslopes and interstream areas and steeper terrain forced the population to occupy the flood plains and alluvial fans, resulting in a high demographic density in the flood-prone areas.

The unfavorable background conditions are not the only factors responsible for the significant impact on the local population. Thus, the damages could have been mitigated if the flood risk management measures had been properly adopted. a)

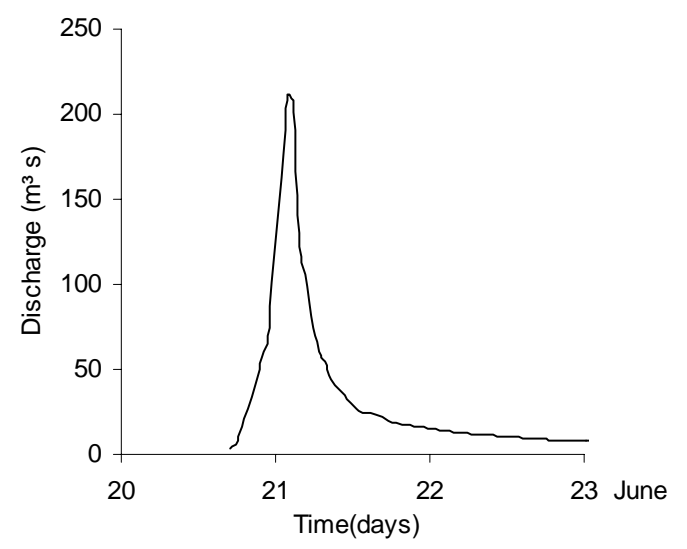

b)

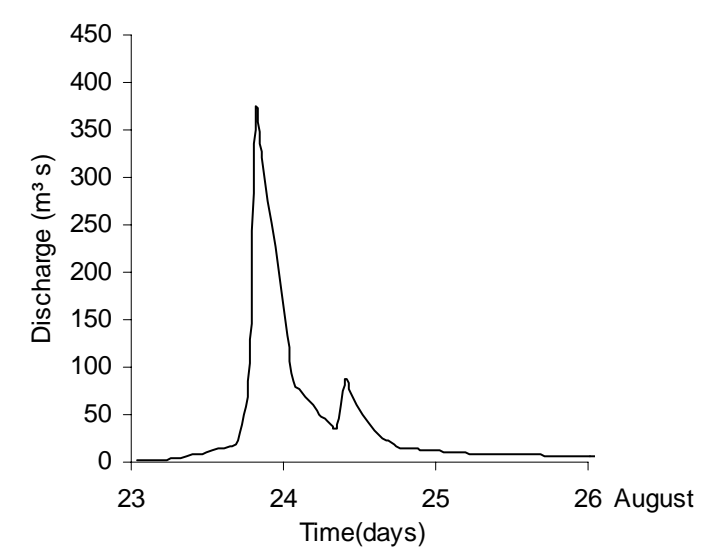

Fig. 5. Flash-flood hydrographs recorded at: (a) Cristeştii-Ciceului streamgauge station - June 2006 Ilişua event; (b) Şimoneşti streamgauge station - August 2005 Feernic event (source of data: Romanian Waters National Administration, RWNA).

Unfortunately, in the study region, no important flood control works (embankments, permanent or temporary reservoirs and channelization works) have been done. On the other hand, especially in the Ilişua Basin, extensive deforestation activities in the steeper terrains were carried out. Such activities have restricted the forest's functions and have generated large amounts of debris wood that formed instable dams in narrow cross sections during the events. As in the entire country, another problem is related to the continuous expansion of the constructed areas and the growth of the building density in the flood-prone areas. Normally, in these areas building restrictions should have been applied.

Flash floods affecting localities that belong to the Feernic, Ilişua or Ciunga basins were possible even with the implementation of leading technologies that provide nowcasting warnings. Unfortunately, although the meteorological warnings were clearly formulated, the Romanian Flash 

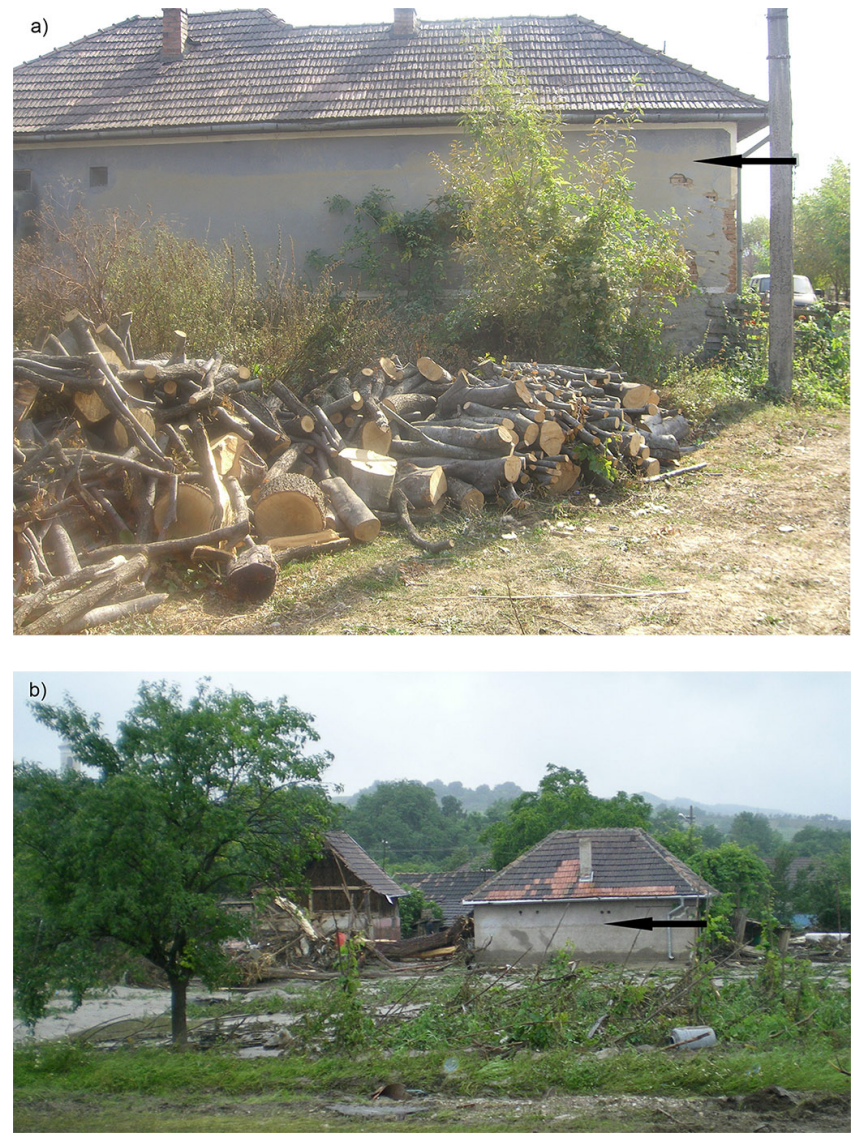

Fig. 6. The flash-flood marks in the affected areas: (a) Lupeni village - Feernic Basin; (b) Uioara de Jos village - Ciunga Basin.

Flood Guidance (ROFFG) System was not functional yet. In some situations, a lack of proper reaction and responsibility from the local authorities and even the misunderstanding of the warning messages were noticed. Because in most situations the casualties were helpless elderly people, it became urgent and compulsory to develop a plan for the rapid evacuation of these people whenever an emergency situation would occur.

Although in recent years progress has been made in flood risk management by implementing of the National Strategy for Flood Risk Management (2005) and the Medium and Long Term National Strategy for Flood Risk Management (2010), there are still many issues that must solved. Among these, the following can be spotted:

- a lack of or no feedback on the educational activities among the population regarding the flood risk;

- a lack of sustainable awareness of the administrative authorities involved in operative management of flashflood risk;

- a lack of a specific national strategy for flash-flood risk management;

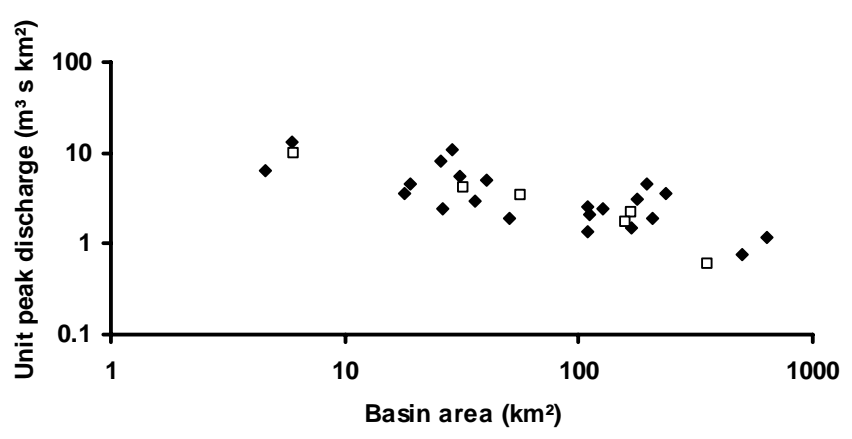

Fig. 7. Relation between the basin area and unit peak discharge for the studied events and other significant flash floods in Romania.

- inefficiency of the national insurance system against natural hazards.

Acknowledgements. The authors would like to thank the Romanian National Meteorological Administration, Romanian Waters National Administration, County Committees for Emergency Situations and County Prefect's Houses for providing the data of the survey.

Edited by: T. Glade

\section{References}

Anquetin, S., Ducrocq, V., Braud, I., and Creutin J. D.: Hydrometeorological modelling for flash flood areas: the case of the 2002 Gard event in France, J. Flood Risk Manag., 2, 101-110, 2009.

Arghiuş, V.: Study of floods on the watercourses in the East part of the Apuseni Mountains and their related risks, Casa Cărţii de Ştiinţă Publishing House, Cluj-Napoca, Romania, 251 pp., 2008 (in Romanian).

Arghiuş, V. and Maloş, C.: Analysis of the maximum precipitations in the East of the Apuseni Mountains, Philobiblon, XIV, 518538, 2009.

Arghiuş, V., Botezan, C., Gagiu, A. C., Samara, I., Senzaconi, F., and Ozunu, A.: Normalised economical flood damages in Romania, 2000-2009, Environ. Eng. Manag. J., 10, 17-22, 2011.

Aronica, G. T., Brigandi, G., and Morey, N.: Flash floods and debris flow in the city area of Messina, north-east part of Sicily, Italy in October 2009: the case of the Giampilieri catchment, Nat. Hazards Earth Syst. Sci., 12, 1295-1309, 2012, http://www.nat-hazards-earth-syst-sci.net/12/1295/2012/.

Barredo J. I.: Normalised flood losses in Europe: 1970-2006, Nat. Hazards Earth Syst. Sci., 9, 97-104, 2009, http://www.nat-hazards-earth-syst-sci.net/9/97/2009/.

Borga, M., Boscolo, P., Zanon, F., and Sangati, M.: Hydrometeorological Analysis of the 29 August 2003 Flash Flood in the Eastern Italian Alps, J. Hydrometeorol., 8, 1049-1067, 2007.

Delrieu, G., Ducrocq, V., Gaume, E., Nicol, J., Payrastre, O., Yates, E., Kirstetter, P. E., Andrieu, H., Ayral, P. A., Bouvier, C., Creutin, J. D., Livet, M., Anquetin, S., Lang, M., Neppel, L., Obled, C., Parent-du-Chatelet, J., Saulnier, G. M., Walpersdorf, A., and 
Wobrock, W.: The catastrophic flash-flood event of 8-9 September 2002 in the Gard region, France: a first case study for the Cevennes-Vivarais Mediterranean Hydro-meteorological Observatory, J. Hydrometeorol., 6, 34-52, available at: http://journals. ametsoc.org/doi/pdf/10.1175/JHM-400.1. (last acces: 17 April 2013), 2005.

Drobot, S. and Parker, D. J.: Advances and challenges in flash flood warnings, Environmental Hazards, 7, 173-178, 2007.

EM-DAT: The International Disaster Database, available at: http: //www.emdat.be/glossary/9, last access: 10 March 2012.

Fetea, P., Sârb, M., Dulău, R., Hăşmăşan, T., and Ciogolia, D.: The exceptional flood from 20-23 June in the Ilişua river basin and its impact on the environment, Ecoterra, 10, 26-28, 2006 (in Romanian).

Foody, G. M., Ghoniem, E. M., and Arnell, N. W.: Predicting locations sensitive to flash flood in an arid environement, J. Hydrol., 292, 48-58, 2004.

Gaume, E.: Post flash-Flood Investigation - Methodological Note, Floodsite European Research Project, Report D 23.2., 62 pp., available at: http://www.floodsite.net/ (last access: 20 January 2013), 2006.

Gaume, E. and Borga, M.: Post-flood field investigations in upland catchments after major flash floods: proposal of a methodology and illustrations, J. Flood Risk Manag., 1, 175-189, 2008.

Gaume, E., Livet, M., Desbordes, M., and Villeneuve, J. P.: Hydrological analysis of the river Aude, France, flash flood on 12 and 13 November 1999, J. Hydrol., 286, 135-154, 2004.

Gaume, E., Bain, V., Bernardara, P., Newinger, O., Barbuc, M., Bateman, A., Blaškovicová, L., Bloschl, G., Borga, M., Dumitrescu, A., Daliakopoulos, I., Garcia, J., Irimescu, A. Kohnova, S., Koutroulis, A., Marchi, L., Matreata, S., Medina, V., Preciso, E., Sempere-Torres, D., Stancalie, G., Szolgay, J., Tsanis, I., Velasco, D., and Viglione, A.: A compilation of data on European flash floods, J. Hydrol., 367, 70-78, 2009.

Hydrate Project, available at: http://www.hydrate.tesaf.unipd. it/WareHouse/EuropeanDataCenter/Romania/, last access: 25 November 2012.

Koutroulis, A. G. and Tsanis, I. K.: A method for estimating flash flood peak discharge in a poorly gauged basin: case study for the 13-14 January 1994 flood, Giofiros basin, Crete, Greece, J. Hydrol., 385, 150-164, 2010.

Manus, C., Anquetin, S., Braud, I., Vandervaere, J.-P., Creutin, J.D., Viallet, P., and Gaume, E.: A modeling approach to assess the hydrological response of small Mediterranean catchments to the variability of soil characteristics in a context of extreme events, Hydrol. Earth Syst. Sci., 13, 79-97, 2009, http://www.hydrol-earth-syst-sci.net/13/79/2009/.
Marchi, L., Borga, M., Preciso, E., Sangati, M., Gaume, E., Bain, V., Delrieu, G., Bonnifait, L., and Pogaènik, N.: Comprehensive post-event survey of a flash flood in Western Slovenia: observation strategy and lessons learned, Hydrol. Process., 23, 37613770, 2009.

Marchi, L., Borga, M., Preciso, E., and Gaume, E.: Characterisation of selected extreme flash floods in Europe and implications for flood risk management, J. Hydrol., 394, 118-133, 2010.

Meteo Romania - The Romanian National Meteorological Administration, available at: http://www.meteoromania.ro/index.php? id=432, last access: 5 March 2012.

Pastor, F., Gómez, I., and Estrela, M. J.: Numerical study of the October 2007 flash flood in the Valencia region (Eastern Spain): the role of orography, Nat. Hazards Earth Syst. Sci., 10, 13311345, doi:10.5194/nhess-10-1331-2010, 2010.

Roca, M. and Davison, M.: Two dimensional model analysis of flash-flood processes: application to the Boscastle event, J. Flood Risk Manag., 3, 63-71, 2010.

Rusjan, S., Kobold, M., and Mikoš, M.: Characteristics of the extreme rainfall event and consequent flash floods in W Slovenia in September 2007, Nat. Hazards Earth Syst. Sci., 9, 947-956, doi:10.5194/nhess-9-947-2009, 2009.

Šálek, M., Brezková, L., and Novák, P.: The use of radar in hydrological modeling in the Czech Republic - case studies of flash floods, Nat. Hazards Earth Syst. Sci., 6, 229-236, doi:10.5194/nhess-6-229-2006, 2006.

Sangati, M.: Flash flood analysis and modelling in mountain regions, Ph.D. thesis, Department of Land, Environment, Agriculture and Forestry, The University of Padova, Italy, 141 pp., available at: http://paduaresearch.cab.unipd.it/1686/1/tesi_dottorato_ Marco_Sangati_090129.pdf (last access: 20 November 2012), 2009.

Stancalie, G., Antonescu, B., Cheval, S., Irimescu, A., and Dumitrescu, A.: Synoptic and regional meteorological ingredients which induced severe flash floods in Romania, presentation at 3rd International Disaster and Risk Conference IDRC Davos, available at: http://www.slideshare.net/GRFDavos/ stancaliedavos2010ppt (last access: 20 November 2012), 2010.

Tarolli, P., Borga, M., Morin, E., and Delrieu, G.: Analysis of flash flood regimes in the North-Western and South-Eastern Mediterranean regions, Nat. Hazards Earth Syst. Sci., 12, 1255-1265, doi:10.5194/nhess-12-1255-2012, 2012.

UNCE, Statistical Database 2000-2010, GDP inflator, available at: http://w3.unece.org/pxweb/database/STAT/20-ME/2-MENA/ ?lang=1 (last access: 12 May 2013), 2012.

Wetterzentrale, available at: http://www.wetterzentrale.de/ topkarten/fsavneur.html, last access:18 February 2012. 